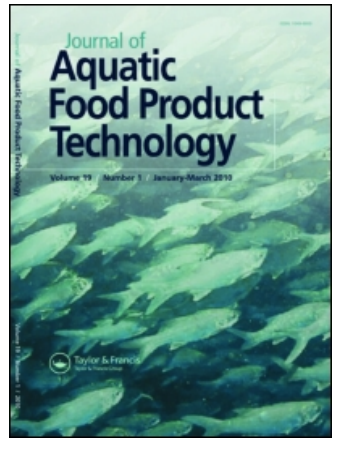

Journal of Aquatic Food Product Technology

\title{
Effect of Salt Concentration and Extremely Halophilic Archaea on the Safety and Quality Characteristics of Traditional Salted Anchovies
}

Antonio Alfonzo, Walter Randazzo, Marcella Barbera, Ciro Sannino, Onofrio Corona, Luca Settanni, Giancarlo Moschetti, Andrea Santulli \& Nicola Francesca

To cite this article: Antonio Alfonzo, Walter Randazzo, Marcella Barbera, Ciro Sannino, Onofrio Corona, Luca Settanni, Giancarlo Moschetti, Andrea Santulli \& Nicola Francesca (2017) Effect of Salt Concentration and Extremely Halophilic Archaea on the Safety and Quality Characteristics of Traditional Salted Anchovies, Journal of Aquatic Food Product Technology, 26:5, 620-637, DOI: 10.1080/10498850.2016.1251521

To link to this article: http://dx.doi.org/10.1080/10498850.2016.1251521

Accepted author version posted online: 28

Nov 2016.

Published online: 28 Nov 2016.

Submit your article to this journal $\pi$

W Article views: 84

View related articles

View Crossmark data $\asymp$

Full Terms \& Conditions of access and use can be found at

http://www.tandfonline.com/action/journallnformation?journalCode=wafp20 


\title{
Effect of Salt Concentration and Extremely Halophilic Archaea on the Safety and Quality Characteristics of Traditional Salted Anchovies
}

\author{
Antonio Alfonzo ${ }^{a}$, Walter Randazzo ${ }^{a}$, Marcella Barbera ${ }^{a}$, Ciro Sannino ${ }^{b}$, Onofrio Corona ${ }^{a}$, \\ Luca Settanni ${ }^{a}$, Giancarlo Moschettia ${ }^{a}$ Andrea Santullic, and Nicola Francesca ${ }^{a}$ \\ aDipartimento Scienze Agrarie e Forestali, Università degli Studi di Palermo, Palermo, Italy; ${ }^{b}$ Dipartimento di Scienze \\ Agrarie, Alimentari ed Ambientali, Perugia, Italy; 'Dipartimento Scienze della Terra e del Mare, Università degli Studi \\ di Palermo, Palermo, Italy
}

\begin{abstract}
Extremely halophilic archaea (EHA) might play an important role in salted fish production. So far, limited information has been available on the effect of EHA and salt concentration on the safety and quality characteristics of salted anchovies. Eight Halobacterium salinarum strains were isolated from different sea salt samples and subjected to phenotypic and genotypic characterization. The strains were then inoculated into fresh salt before addition to anchovies. A total of 18 experimental productions were performed. The inoculated trials showed the lowest counts of undesired microorganisms. In particular, salted anchovies produced with Hbt. salinarum $\mathrm{H} 11$ showed the lowest histamine concentration as well as the highest sensory scores. Differences in terms of volatile organic compounds (VOCs) were estimated among trials. Furthermore, multivariate analysis showed that experimental production performed with a reduced amount of salt $(175 \mathrm{~g}$ of sea salt per $\mathrm{kg}$ of anchovies) did not affect the final quality of salted anchovies. The strain $\mathrm{Hbt}$. salinarum $\mathrm{H} 11$ produced salted anchovies with well-appreciated organoleptic features. Thus, the addition of EHA and the use of a lower amount of sea salt might represent a valuable alternative to the traditional method for production of salted anchovies.
\end{abstract}

\section{KEYWORDS}

Extremely halophilic archaea; Halobacterium salinarum; histamine; salted anchovies; salt concentration

\section{Introduction}

In the Mediterranean basin, the production of salted anchovies (Engraulis encrasicolus L.) is a traditional process that is performed to preserve the fish (Aponte et al., 2010; Hernandez-Herrero et al., 1999). A total of 490,000 tons of anchovies were captured in Europe during the year 2012, and 91,803 tons were transformed by salting and/or brining (FAO, 2014). Traditionally, production of salted anchovies begins with beheading and gutting of fresh fishes. After that, the anchovies are disposed "head-tail" in glass jars (technically known as "arbanelle" with $3 \mathrm{~L}$ volume capacity), and salt is added (about $500 \mathrm{~g}$ of salt per $\mathrm{kg}$ of anchovies) layer by layer. Karaçam et al. (2002) demonstrated that the amount of salt used $(22-26 \% \mathrm{w} / \mathrm{v}$ brine solution) for the production of brined anchovies is of considerable importance; in particular, the product obtained with higher concentration of salt is more appreciated by consumers. So far, the amount of salt used during anchovy productions is determined only by a traditional and popular recipe based on a salt/fish ratio of 1:2 (Aponte et al., 2010). Karaçam et al. (2002) investigated the quality of anchovies brined at different concentrations; they showed that different amounts of salt added to brine might significantly affect

CONTACT Nicola Francesca nicola.francesca@unipa.it Dipartimento Scienze Agrarie e Forestali, Università degli Studi di Palermo, Viale delle Scienze 4, 90128 Palermo, Italy.

Color versions of one or more of the figures in the article can be found online at www.tandfonline.com/wafp 
the sensory, chemical, and microbiological characteristics of salted anchovies. Lee et al. (2015) reported that the quality of salted-fermented anchovies changes by varying the amount of salt during production at $15^{\circ} \mathrm{C}$ for 110 days. Sensory analysis has resulted in a product with a minimum amount of salt (15\%) acceptable to consumers. Furthermore, the different concentration of salt during salted fish storage might affect many enzyme activities; thus, the chemical composition of the final products could change (Lee et al., 2015).

Previous microbial characterization of salted anchovies reported a variety of microbial populations, such as halotolerant and halophilic microorganisms (often belonging to the Halobacteriaceae family) (Caseario and Caramaschi, 1993; Hernandez-Herrero et al., 1999; Villar et al., 1985), lactic acid bacteria, Enterobacteriaceae, enterococci, and staphylococci (Aponte et al., 2010; HernandezHerrero et al., 1999). Halophilic microorganisms have been investigated not only in saline environments (Birbir et al., 2007; Grant et al., 1998; Oren, 2006), but also in food ecosystems (Aponte et al., 2010; Lee, 2013; Tapinkage et al., 2010; Yeannes et al., 2011), as they are considered to be the spoilage bacteria of meat and fish products due to their red/pink color and enzymatic activities (Eddy, 1958; Petter, 1931).

Previously, several species of Halobacterium sp. have been considered as potential spoilage microorganisms during ripening of salted fishes (Bronwn, 2008; Hall, 1997; Heredia et al., 2009; Troller and Christian, 1978). Recently, several studies of food ecosystems, especially those carried out on the conservation of fish products, tested the use of archaea as the starter during the ripening of salted anchovies. These fish products normally require a long time before reaching the consumer.

Many other studies investigated the ability of extremely halophilic archaea (EHA) strains to produce enzymes, in particular proteases, for food applications (Akolkar et al., 2010; Gimenez et al., 2000; Izotova et al., 1983; Kamekura et al., 1992; Ryu et al., 1994; Schmitt et al., 1990; Shi et al., 2006; Stepanov et al., 1992; Studdert et al., 2001; Vidyasagar et al., 2006). Most of the proteases produced by halophilic bacteria are extracellular serine proteases, which retain their enzymatic capacities even at high salt concentrations. Akolkar et al. (2010) reported that the inoculation of Halobacterium sp. SP1 (a red-pink color shape culture) into salted fishes shortened the ripening and improved the chemical composition (amino acids profile) and the flavor of the final products. Furthermore, Aponte et al. (2010) clearly showed that the use of red-pink color shape archaea halophilic strains as the starter might significantly improve both the safety and the sensory quality of salted anchovies (Engraulis encrasicolus), while no color alteration was recognized by panelists.

During the production of salted anchovies, several physico-chemical changes occur in fish tissues. First, the diffusion of salt occurs with the consequent elimination of water from fish tissues. Temperature, freshness of fish, and the relative fat content, as well as the thickness of muscle, might vary the rate of salt penetration (Clucas, 1982). The ripening is induced by enzymes that decompose proteins and fats (Voskresensky, 1965). The enzymatic pathways that occur are attributed to tissue and/or microbial enzymes (Hernandez-Herrero et al., 1999). The value of water activity of salted products might affect the growth of microbial population as well as the activities of many enzymes (Filsinger, 1987). Another main factor during salted anchovy production is the generation of histamine (Lehane et al., 2000), which, at high concentration, is detrimental to the quality and safety of the final product (EFSA, 2011). The European Commission has issued two Commission Regulations (EC No. 1441/2007; EC No. 1019/2013) establishing the histamine limit for ripened brined/salted fishery products at $400 \mathrm{mg} / \mathrm{kg}$ of fish. The histamine compound is mainly produced by histamine decarboxylase enzymes originating from many species of microorganisms and enzymes of animal origin. On the other hand, many bacteria strains used as starter strains for food production have been evaluated for their ability to degrade histamine compounds. Thus, the use of those starter cultures might be a useful tool to reduce the amount of histamine in foods (Bakke et al., 2005; Ienistea et al., 1971). Recently, Tapingkae et al. (2010) reported the degradation of histamine to a large extent by EHA that are the microbial group isolated from salted fish products.

To our knowledge, no studies have investigated the effect of the salt amount on the chemical, microbiological, and sensory quality of salted anchovies. Hence, the present research was aimed to 
study (I) the effect of different concentrations of sea salt to produce salted anchovies and concomitantly (II) the effect of eight EHA strains isolated from different sea salts. Microbiological, chemical, and sensory parameters were monitored during the entire anchovy production in order to evaluate the final quality and safety of the resulting products.

\section{Materials and methods}

\section{Collection of salt samples and microbiological analyses}

A total of 14 samples (Table 1) of commercial salt from salt pans and mines were purchased from local markets or salt enterprises of Sicily (southern Italy). Salts were transferred into sterile Stomacher bags and kept at room temperature until analysis. The sampling was performed in triplicate on different days.

Salt samples were screened for the presence of EHA according to the protocol reported by Moschetti et al. (2006). To this purpose, each sample (10 g) was inoculated into a $500 \mathrm{ml}$ conical flask containing $250 \mathrm{ml}$ Halobacterium liquid medium (HLM) for the enrichment (Oren et al., 1999). Flasks were incubated for two weeks at $44^{\circ} \mathrm{C}$ under constant shaking $(150 \mathrm{rpm})$ and lighting. Ten milliliters of each culture was transferred to a new flask with $250 \mathrm{ml}$ HLM. After three subcultures, $100 \mu \mathrm{l}$ were spread on Halobacterium medium agar (HMA) and incubated at $44^{\circ} \mathrm{C}$ for two weeks. Analyses were performed in triplicate. All media and the supplements were supplied from Oxoid (Milan, Italy).

\section{Isolation and phenotypic characterization of EHA}

Presumptive EHA (at least four colonies with the same color, morphology, edge, surface, and elevation) were collected from HMA plates. The isolates were purified by successive sub-culturing, and the purity of the isolates was checked microscopically.

Rod-shaped cell, Gram-negative, catalase (determined in presence of $\mathrm{H}_{2} \mathrm{O}_{2} 5 \%$, v/v), and oxidase (determined with tetramethyl phenylendiamine- $\mathrm{HCl}$ ) positive isolates were stored in HLM containing $20 \%(\mathrm{v} / \mathrm{v})$ glycerol at $-80^{\circ} \mathrm{C}$ until further experimentations. EHA were initially subjected to a phenotypic characterization based on nitrate reduction (Hassanshahian, 2011), gas production from nitrate (Hassanshahian, 2011), anaerobic growth in presence of L-arginine (Oren and Litchfield, 1999), and production of acids from glucose (Rodriguez-Valera et al., 1983).

All tests were carried out in three independent replicates according to the protocol reported by Holt et al. (2005).

Table 1. Salt samples used in this study and origin of the EHA isolates

\begin{tabular}{|c|c|c|c|c|}
\hline Samples & Company & Geographical origin & Source & $\mathrm{nb}$ of isolates \\
\hline SS1 & Saline Ettore e Infersa S.R.L. & Marsala (TP) & Salt pan & 61 \\
\hline SS2 & Sosalt S.P.A. & Trapani/Marsala (TP) & Mix salt pans & 84 \\
\hline SS3 & Sale e Mediterraneo S.R.L.S. & Trapani (TP) & Salt pan & 25 \\
\hline SS4 & Sikeli'a S.R.L. & Marsala/Trapani (TP) & Mix salt pans & 65 \\
\hline SS5 & Sosalt S.P.A. & Trapani/Marsala (TP) & Mix salt pans & 0 \\
\hline SS6 & Sale e Mediterraneo S.R.L.S. & Trapani (TP) & Salt pan & 32 \\
\hline SS7 & Sikeli'a S.R.L. & Marsala/Trapani (TP) & Mix salt pans & 0 \\
\hline SS8 & Italkali S.P.A. & Petralia (PA), Realmonte, Racalmuto (AG) & Mix salt mines & 0 \\
\hline SS9 & Sale di Raimondo & Trapani/Marsala (TP) & Mix salt pans & 0 \\
\hline SS10 & Iblea Sale di Borrometi G. \& C. S.N.C. & Trapani/Marsala (TP) & Mix salt pans & 0 \\
\hline SS11 & Naso Carlo & Trapani & Mix salt pans & 0 \\
\hline SS12 & Sale Cucchiara S.R.L. & Trapani/Marsala (TP) & Mix salt pans & 0 \\
\hline SS13 & Roccella Ettore & Trapani/Marsala (TP) & Mix salt pans & 0 \\
\hline SS14 & Italkali S.P.A. & Petralia (PA), Realmonte, Racalmuto (AG) & Mix salt mines & 0 \\
\hline
\end{tabular}




\section{Genotypic investigation of EHA at the strain and species level}

Genomic DNA from EHA cultures was extracted with the InstaGene Matrix kit (Bio-Rad, Hercules, CA, USA) according to the manufacturer's instructions. Before DNA extraction, cell cultures were washed twice in sterile $25 \%(\mathrm{w} / \mathrm{v})$ salt water.

Strain differentiation was performed by polymorphic random amplified polymorphic DNApolymerase chain reaction (RAPD-PCR) analysis in a $25 \mu \mathrm{L}$ reaction mix using the single primers XD9, PRIMM 239, and XD4 as previously described by Moschetti et al. (2006).

RAPD amplicons were separated by electrophoresis on a $2 \%(w / v)$ agarose gel (Gibco BRL, Cergy Pontoise, France), stained with SYBR ${ }^{\circ}$ Safe DNA gel stain (Molecular Probes, Eugene, OR, USA) and subsequently visualized by UV transillumination. The GeneRuler 100 bp Plus DNA Ladder (MMedical S.r.l., Milan, Italy) was used as a molecular size marker. RAPD patterns were analyzed using the Gelcompare II software, version 6.5 (Applied-Maths, Sint-Martens-Latem, Belgium).

One representative strain for each RAPD profile was identified at species level by 16S rRNA gene sequencing as described by Moschetti et al. (2006). The primers used to amplify the 16S rRNA gene were ARCH1 and ARCH2 (Moschetti et al., 2006). The 16S rRNA gene amplicons were visualized as reported above.

DNA sequencing reactions were performed by PrimmBiotech srl (Milan, Italy). The identities of the sequences were determined by BLASTN search against the NCBI non-redundant sequence database located at http://www.ncbi.nlm.nih.gov (Altschul et al., 1997) and those available at EzTaxon-e database at http://www.ezbiocloud.net/eztaxon (Chun et al., 2007).

\section{Production of experimental anchovies}

All strains belonging to the EHA group were independently inoculated into commercial salt (Sale Cucchiara S.R.L., Trapani/Marsala, Italy), according to the procedure described by Aponte et al. (2010). All salt samples used for the experimental trials were subjected to heat treatment for $2 \mathrm{~h}$ at $160^{\circ} \mathrm{C}$. Subsequently, the salt was sterilized at $121^{\circ} \mathrm{C}$ for $20 \mathrm{~min}$ (Prasad et al., 1995). Furthermore, microbiological analysis and PCR amplification of the archaeobacterial 16S rRNA gene were performed to ascertain the absence of halophilic archaea in sterilized commercial salt to be used in the experimental trials (Moschetti et al., 2006; Prasad et al., 1995). The inoculated salts were used to produce experimental salted anchovies. Fresh anchovies were purchased from a local fish market located in Palermo (Italy) and immediately transferred to the laboratory. The experimental production of salted anchovies was carried out according to the protocol of Aponte et al. (2010). Each jar was filled with $2 \mathrm{~kg}$ of anchovies. The jars with 125 and $175 \mathrm{~g}$ of inoculated salt per each $\mathrm{kg}$ of anchovies represented the trials $a$ and $b$, respectively. Per each EHA strain, both amounts of salt ( $a$ and $b$ ) were included in the experimental design. In addition, three different control productions (without EHA addition) were included for comparison: control 1- $a$, control 1- $b$, and control 2 were performed with 125,175 , and $500 \mathrm{~g} / \mathrm{kg}$ of salt, respectively.

To maintain anchovies under constant pressure, a weight of $2 \mathrm{~kg}$ was placed above the jars for the first month, and after that, it was reduced to $1 \mathrm{~kg}$ until the end of ripening (150 days).

The ripening was carried out at $20^{\circ} \mathrm{C}$ for 150 days, and it was periodically monitored. Samples of salted anchovies (about $50 \mathrm{~g}$ ) were collected before and immediately after the addition of sterile salt and at 3, 6, 12, 24, 48, 96, and 150 days of ripening. The experiment was conducted in triplicate (three jars per trial).

\section{Monitoring of microbial populations of experimental anchovies}

Samples of anchovies were suspended in Ringer's solution (Sigma-Aldrich, Milan, Italy) at a ratio of 1:10 (w/v), homogenized with a stomacher (BagMixer ${ }^{\circledR} 400$, Interscience, St Nom. France) for 4 min at the maximum speed, and subjected to decimal dilutions. The following microbial groups were 
enumerated: the total aerobic mesophilic microorganisms on plate count agar (PCA) incubated at $30^{\circ} \mathrm{C}$ for $72 \mathrm{~h}$; mesophilic lactic acid bacteria (LAB) on de Man-Rogosa-Sharpe (MRS) agar incubated at $30^{\circ} \mathrm{C}$ for $48 \mathrm{~h}$; Enterobacteriaceae on double-layer violet red bile glucose agar (VRBGA), incubated at $37^{\circ} \mathrm{C}$ for $24 \mathrm{~h}$; staphylococci on Baird Parker (BP) and coagulase positive staphylococci (CPS) on BP added with $\mathrm{RPF}$ supplement, incubated at $37^{\circ} \mathrm{C}$ for $48 \mathrm{~h}$ (APHA, 2015). For the enumeration of halophilic microbial populations, samples of anchovies were suspended in a modified Ringer's solution $(25 \% \mathrm{w} / \mathrm{v} \mathrm{NaCl})$ (Moschetti et al., 2006; Aponte et al., 2010), ratio 1:10 (w/v). Furthermore, they were counted on Halobacterium medium after incubation at $44^{\circ} \mathrm{C}$ for 15 days under constant light. All media and supplements were purchased from Oxoid. All analyses were performed in triplicate.

The presence of EHA strains inoculated into salt was monitored by phenotypic and genotypic analysis as reported above.

\section{Histamine determination}

The content of histamine in salted anchovies at 150 days of ripening was determined by acid extraction and derivatization of histamine. The analysis was performed by the modification of the methods reported by Erola et al. (1992) and Moret et al. (1996). Stock standard solutions containing histamine dihydrochloride (Sigma-Aldrich) and 1.7 diaminoheptane (as internal standard) were prepared by adding a weighed amount of histamine in ultrapure water (Easypure II, Thermo) at a concentration of $1000 \mathrm{mg} / \mathrm{l}$. The standard solution was stored at $4^{\circ} \mathrm{C}$ until use. Homogenized anchovies $(5 \mathrm{~g})$ were added to $10 \mathrm{ml}$ of $\mathrm{HCl} 0.1 \mathrm{M}$, containing $100 \mathrm{mg} / \mathrm{l}$ of the internal standard and homogenized with an Ultra-Turrax system (T 25 basic IKA labortechnik, Staufen, Germany). The mixture was centrifuged at $4000 \mathrm{rpm}$ for $30 \mathrm{~min}$ at $4^{\circ} \mathrm{C}$, and the supernatant was separated through $0.45 \mu \mathrm{m}$ filters (Sartorius, Muggiò, Italy). The extraction was repeated for the solid residue. The two acid extracts were mixed and diluted up to $25 \mathrm{ml}$ with $\mathrm{HCl} 0.1 \mathrm{M}$. An aliquot of $1 \mathrm{ml}$ of the acid extract was mixed with $0.5 \mathrm{ml}$ of saturated $\mathrm{NaHCO}_{3}$ solution and $1.0 \mathrm{ml}$ of dansyl chloride solution $\left(5 \mathrm{mg} / \mathrm{ml}\right.$ in acetone) and kept in darkness for $1 \mathrm{~h}$ at $40^{\circ} \mathrm{C}$. The residual dansyl chloride was removed by adding $300 \mu \mathrm{l}$ of ammonia solution (30\%), and each sample, shielded from light, reacted for $15 \mathrm{~min}$ at room temperature. Each sample was extracted twice with $1 \mathrm{ml}$ of diethyl ether. The combined extracts were dried, and the residue was dissolved with $1 \mathrm{ml}$ of acetonitrile and then injected into a high performance liquid chromatography (HPLC) system. The analyses and quantification of dansylated histamine were carried out by an Agilent 1200 HPLC system equipped with a G1329A high performance autosampler G1316A Thermostated Column Compartment and G1315D $\mathrm{DAD}$ detector (Diode Array Detector) injecting $20 \mu \mathrm{l}$ of each sample. The peaks were integrated at $254 \mathrm{~nm}$. The separation was carried out using an Agilent Eclipse XDB-C18 $(4.6 \times 150 \mathrm{~mm}, 5 \mu \mathrm{m})$ column. The mobile phases were ultrapure water (A) and acetonitrile (B) eluting under gradient condition with a flow rate of $1 \mathrm{ml} / \mathrm{min}$. The gradient elution program was as follows: $0-12 \mathrm{~min}$, $50-80 \%$ B, $12-25 \mathrm{~min}, 80-100 \%$ B, 25-30 min 100-50\% B. An external calibration was obtained by analyzing six standard solutions at different concentrations derivatized as describe above for the samples. All analyses were performed in triplicate.

\section{Volatile organic compounds}

Volatile organic compounds (VOCs) were determined at 150 days of ripening of salted anchovies by solid-phase micro-extraction-gas chromatography-mass spectrometer (SPME-GC/MS) technique. Five grams of homogenized salted anchovies were transferred into $20 \mathrm{ml}$ vials with pierceable polytetrafluoroethylene (PTFE)/silicone septa 27136 (Supelco, Bellefonte, Italy).

A SPME fiber of divinylbenzene/carboxen/polydimethylsiloxane (DVB/CAR/PDMS; Supelco, Bellefonte, Italy) was used and conditioned at $250^{\circ} \mathrm{C}$ for $30 \mathrm{~min}$ in the GC/MS injector before each extraction. For the extraction, the SPME fiber was inserted into a sample vial through the septum and then exposed to the headspace gas for $30 \mathrm{~min}$ at $40^{\circ} \mathrm{C}$. The fiber was retrieved and 
injected into the GC/MS system. One hundred fifty $\mu \mathrm{L}$ of 1-heptanol solution (35mg/l 1-heptanol in $20 \%$ ethanol aqueous solution) was used as an internal standard.

The SPME fiber was directly inserted into a Finnegan Trace MS for GC/MS (Agilent 6890 Series GC system, Agilent 5973 Net Work Mass Selective Detector; Milan, Italy) equipped with a DB-WAX capillary column (Agilent Technologies; $30 \mathrm{~m} .0 .250 \mathrm{~mm}$ i.d. film thickness $0.25 \mu \mathrm{m}$, part no 122-7032). During the split less injection, the GC temperature was set at $40^{\circ} \mathrm{C}$ for the first $2 \mathrm{~min}$, then increasing $4^{\circ} \mathrm{C} / \mathrm{min}$ from $40^{\circ} \mathrm{C}$ to $60^{\circ} \mathrm{C}$, followed by a break at $60^{\circ} \mathrm{C}$ for $2 \mathrm{~min}$, and then from $60^{\circ} \mathrm{C}$ to $190^{\circ} \mathrm{C}$, increasing $2^{\circ} \mathrm{C} / \mathrm{min}$, from $190^{\circ} \mathrm{C}$ to $230^{\circ} \mathrm{C}$, increasing $5^{\circ} \mathrm{C} / \mathrm{min}$, and finally $230^{\circ} \mathrm{C}$ for $15 \mathrm{~min}$. The GC injector was at $250^{\circ} \mathrm{C}$, the Fid at $250^{\circ} \mathrm{C}$, the transfer line at $230^{\circ} \mathrm{C}$, with helium as carrier at a rate of $1 \mathrm{ml} / \mathrm{min}$, and $\mathrm{EM}$ at $70 \mathrm{eV}$. Mass spectra were recorded by electronic impact at $70 \mathrm{eV}$ using the ion source temperature of $200^{\circ} \mathrm{C}$. All compounds of $\mathrm{m} / z$ 33-495 atomic mass units (amu) were detected with this scan mode. Individual peaks were identified by comparing their retention indices to those of control samples and by comparing their mass spectra with those within the NIST/EPA/NIH Mass Spectral Library database (Version 2.0d. build 2005). Volatile compounds were expressed as $\mu \mathrm{g} / \mathrm{kg}$. All solvents and reagents were purchased from WWR International (Milan, Italy). All analyses were performed in triplicate.

\section{Sensory analysis}

The evaluation of the sensory profiles of the ripened salted anchovies was performed following the descriptive method ISO 5496:2006.

Ten judges were trained in preliminary sessions using different samples of commercial salted anchovies in order to develop a common vocabulary for the description of the sensory attributes as well as to familiarize them with scales and procedures. Each attribute was extensively described and explained to avoid any doubt about the relevant meaning. The descriptors related to aspect (color uniformity and color intensity), texture (compactness, juicy, and gummy), odor (salt anchovies), flavor (ham taste, rancid, and putrid), and overall acceptability were included in the analyses. The anchovies were randomly evaluated by assigning a score between 1.00 (absence of descriptor sensation) and 9.00 (extremely intense) in individual booths under incandescent white light. Two panel replications were carried out per sample.

\section{Statistical and explorative multivariate analyses}

Data obtained from microbiological investigation and sensory evaluation were analyzed using a generalized linear model (GLM) that included the effects of samples; the Student " $t$ " test was used for mean comparison. The analysis of variance (ANOVA) test was applied to identify significant differences among microbial counts. The post-hoc Tukey's method was applied for pairwise comparison in case of microbial counts, histamine, and sensory scores. Statistical significance was attributed to $p$ values of $p<0.05$.

In addition, an explorative multivariate approach was employed to investigate relationships among data obtained from the different experimentations.

A hierarchical cluster analysis (HCA) was carried out for grouping the experimental trials according to their similarity, measured by Euclidean distances; whereas cluster aggregation was based on the single linkage method (Todeschini, 1998). Furthermore, principal component analysis (PCAn) was employed to investigate relationships among samples. The input matrix used for HCA and PCAn consisted of the total area under growth/decline curves of the total aerobic mesophilic microorganisms, LAB, Enterobacteriaceae, CPS as well as histamine values, VOCs, and results of sensorial profiles (Bautista-Gallego et al., 2011; Blana et al., 2014; Rodríguez-Gómez et al., 2014). Areas were calculated by integration using the OriginPro 7.5 software (OriginLab Corporation, Northampton, MA, USA). The number of principal factors was selected according to the Kaiser criterion (Jolliffe, 1986); only factors with eigen-values higher than 1.00 were retained.

All data were preliminary evaluated using the Barlett's Sphericity test (Dillon and Goldstein, 1984; Martorana et al., 2015) in order to check the statistically significant difference among samples within each dataset. 
Statistical data processing and graphic construction were achieved using STATISTICA software version 10 (StatSoft Inc., Tulsa, OK, USA) and XLStat software version 2014.5.03. (Addinsoft, New York, NY, USA) for Excel.

\section{Results and discussion}

\section{Isolation and characterization of EHA strains from salt samples}

Three hundred fifteen colonies were isolated from the 14 salt samples. After purification and characterization based on colony appearance and microscopic inspection, a total of 267 rods were further phenotypically investigated. All cultures were considered presumptive EHA, because they were Gram-negative, oxidase and catalase positive, motile, as well as able to grow in $25 \% \mathrm{NaCl}$.

The reduction of nitrate, production of gas from nitrate and glucose, as well as the growth on arginine were negative for all strains.

All isolates were subjected to RAPD analysis (data not shown), revealing the presence of 8 strains (Figure 1). The DNA from the eight strains were subjected to specific PCR analyses that target a 16S rRNA fragment highly conserved in Halobacteriaceae. The results of sequencing (Figure 1) showed that all strains belonged to species Hbt. salinarum (identity of at least $98.66 \%$ in EzTaxon-e database) (Stackebrandt and Goebel, 2006). Within the Halobacteriaceae family, the genus Halobacterium is mostly studied, and the species Hbt. salinarum was the first halophilic archaeon described. Hbt. salinarum was isolated from salt rich environments as salted cowhide and cured codfish. In our investigation, $\mathrm{Hbt}$. salinarum was the only species of extremely halophilic archaea detected in Sicilian sea salts.

\section{Evolution of microbiological parameters during production of experimental salted anchovies}

The microbiological loads registered for the experimental salted anchovies are reported in Figure 2.

Salt samples inoculated with the selected strains showed a concentration of EHA population of about $4 \mathrm{Log}$ CFU/g. Moreover, the PCR amplification of the archaeobacterial 16S rRNA gene confirmed that no salt sample contained DNA of archaeal origin.

Both experimental anchovy productions ( $a$ and $b$ ) obtained with inoculated salt showed concentration of EHA higher than that of controls. The experimental productions were not characterized for the presence of other microbial groups. During the entire period of monitoring, the EHA population was almost constant at values about $3.5 \mathrm{Log} \mathrm{CFU} / \mathrm{g}$ in all inoculated trials. RAPD analysis showed that all inoculated strains dominated the EHA population during the entire ripening period of experimental productions.

At time zero, the total aerobic mesophilic microorganisms, LAB, Enterobacteriaceae, and staphylococci showed levels between 1.80-3.90 Log CFU/g in production $a$. Similar values (1.32-3.85 Log $\mathrm{CFU} / \mathrm{g}$ ) were recorded in samples of production $b$.
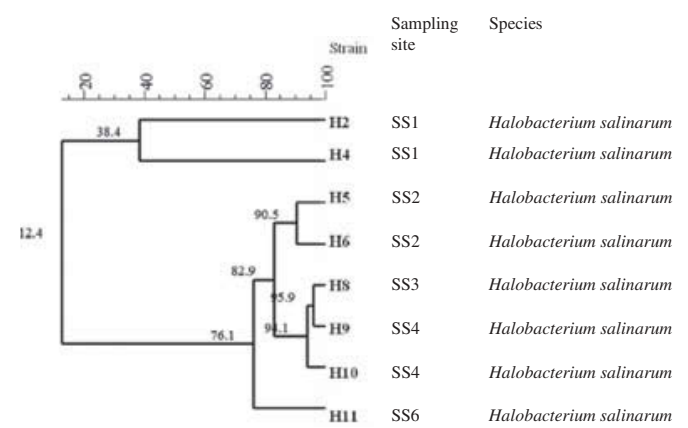

$\begin{array}{llll}\begin{array}{l}\text { \% similarity (accession no. of closest relative) } \\ \text { by: } \\ \text { GenBank }\end{array} & \begin{array}{l}\text { Sequence } \\ \text { length } \\ \text { (bp) }\end{array} & \begin{array}{l}\text { Accession } \\ \text { no. }\end{array} \\ 99 \text { (KF668248.1) } & 99.71 \text { (AE004437) } & 1.393 & \text { KP751335 } \\ 99 \text { (NR_074204.1) } & 98.94 \text { (AE004437) } & 1.415 & \text { KP751336 } \\ 99 \text { (NR_074204.1) } & 99.09 \text { (AE004437) } & 1.425 & \text { KP751337 } \\ 99 \text { (NR_074204.1) } & 98.66 \text { (AE004437) } & 1.421 & \text { KP751338 } \\ 100 \text { (NR_074204.1) } & 99.15 \text { (AE004437) } & 1.417 & \text { KP751339 } \\ 98 \text { (NR_074204.1) } & 98.87 \text { (AE004437) } & 1.418 & \text { KP751340 } \\ 99 \text { (NR_074204.1) } & 99.08 \text { (AE004437) } & 1.419 & \text { KP751341 } \\ 100 \text { (NR_074204.1) } & 98.73 \text { (AE004437) } & 1.420 & \text { KP751342 }\end{array}$

Figure 1. Identification of EHA strains isolated from sea salts. The dendrogram obtained from combined RAPD-PCR patterns of EHA strains generated with three primers (XD9, PRIMM 239, and XD4). The upper line indicates the percentage of similarity. 

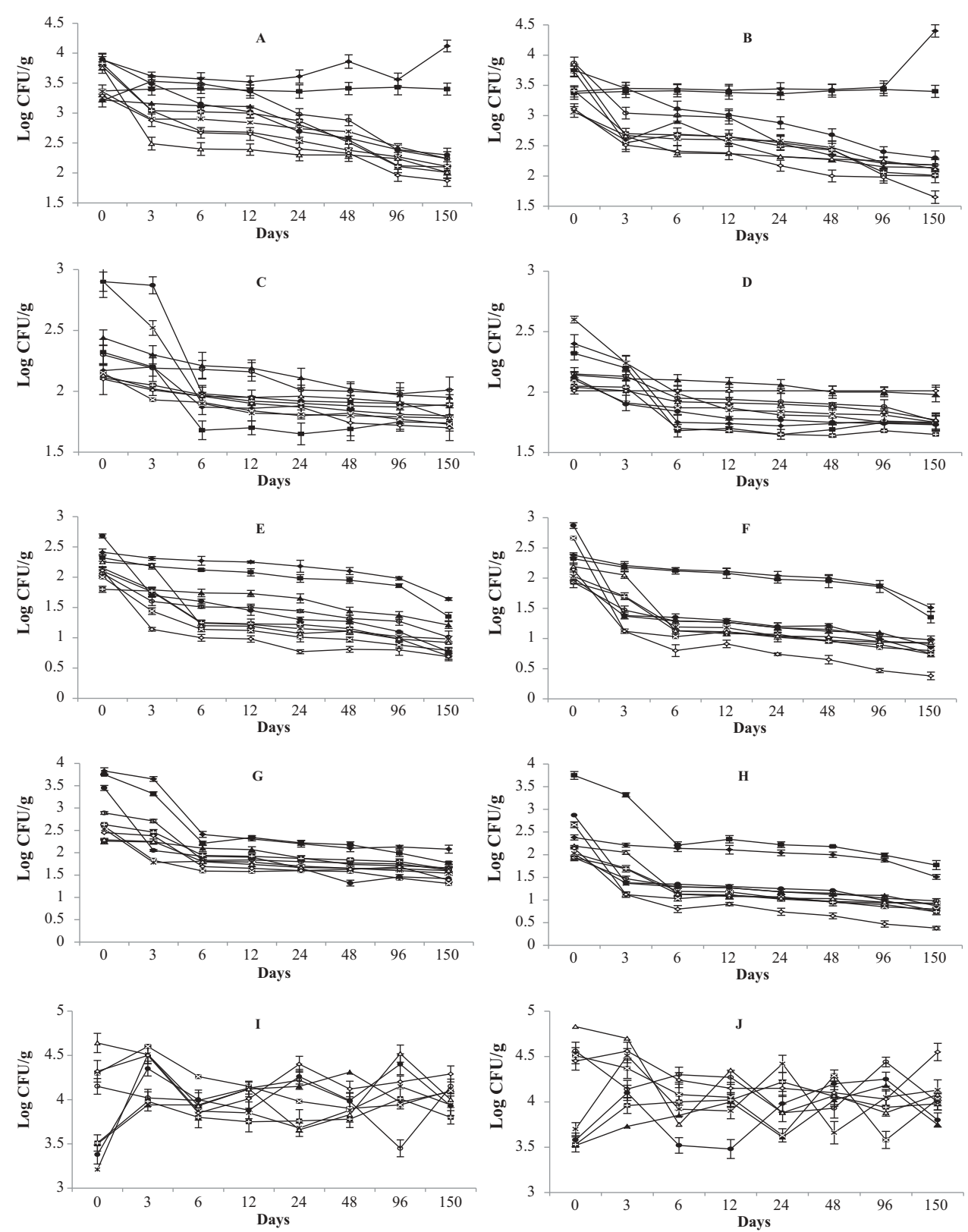

Figure 2. Microbiological concentrations (Log CFU/g) of samples during production of salted anchovies. A, PCA trial $a ; \mathbf{B}$, PCA trial $b$; C, MRS trial $a$; D, MRS trial $b$; E, VRBGA trial $a$; F, VRBGA trial $b$; G, BP trial $a$; H, BP trial $b$; I, HMA trial $a$; J, HMA trial $b$. Symbols: $\checkmark$, Control 1; $\mathbf{\square}$, Control 2; $\mathbf{\Lambda}, \mathrm{H} 2 ;, \mathrm{H} 4 ;{ }^{*}, \mathrm{H} 5 ; \bullet, \mathrm{H} 6 ;, \mathrm{H} 8 ; \mathrm{O}, \mathrm{H} 9 ;, \mathrm{H} 10 ; \diamond, \mathrm{H} 1$. Abbreviation: PCA, plate count agar for total aerobic mesophilic microorganisms; MRS, Man-Rogosa-Sharpe agar for mesophilic rod LAB; VRBGA, violet red bile glucose agar for Enterobacteriaceae; BP, baird parker for Staphylococcaceae; HMA, halobacterium medium agar for extremely halophilic bacteria. The italic letters, $a$ and $b$, refer to the amounts of salt, 125 and $175 \mathrm{~g} / \mathrm{kg}$ respectively, used to produce salted anchovies. Control 2 , experimental production obtained by $500 \mathrm{~g}$ salt per $1 \mathrm{~kg}$ anchovies. $\mathrm{H} 2, \mathrm{H} 4, \mathrm{H} 5, \mathrm{H} 6, \mathrm{H} 8, \mathrm{H} 9, \mathrm{H} 10, \mathrm{H} 11$ refer to codes of Halobacterium salinarum strains used as inoculum. 
During ripening, the microbial counts of all experimental productions $b$ ( $175 \mathrm{~g} / \mathrm{kg}$ of salt) were slightly lower than $a(125 \mathrm{~g} / \mathrm{kg}$ of salt) for all media. Overall, the inoculum of EHA resulted in a decrease of microbial populations of Enterobacteriaceae and staphylococci. The microbial growth of Enterobacteriaceae and staphylococci decreased. HMA counts were almost constant during ripening, and the presence of LAB did not seem to be influenced by the inoculation of different strains of EHA used.

In detail, the total aerobic mesophilic microorganisms showed concentrations of about 3 Log $\mathrm{CFU} / \mathrm{g}$ in samples produced with inoculated salt until 96 days of ripening. Subsequently, the microbial loads were lower than $2 \mathrm{Log} \mathrm{CFU} / \mathrm{g}$, except for controls, which showed values higher than 3.5 Log CFU/g. Furthermore, both productions $a$ and $b$ inoculated with the strain H11 showed the lowest count of all microbial groups until the end of ripening. On the contrary, control productions showed counts of Enterobacteriaceae and staphylococci significantly higher than the inoculated trials.

Data obtained in the present study comply with the trend reported in the literature by several authors (Aponte et al., 2010; Hernández-Herrero et al., 1999). The reduction of microbial loads detected for the total aerobic mesophilic microorganisms, Enterobacteriaceae, and Staphylococcaceae might be due to the high concentration of salt that determines a low water activity (Barros and Lenovich, 1992; Lupin et al., 1981). However, these determined favorable conditions for halophilic archaeal growth (Campello, 1985; Perez-Villarreal and Pozo, 1992). The population of the LAB was not influenced by the amount of salt or the presence of EHA inoculated in the different productions. No statistically significant differences were found in terms of microbial counts between the control $1-b$ and control 2 .

\section{Concentration of histamine}

The concentrations of histamine in ripened anchovies are shown in Figure 3. The highest concentration $(54.61 \mathrm{mg} / \mathrm{kg}$ ) was found for control 1-a, which was also characterized by the highest counts of microbial populations (total aerobic mesophilic microorganisms, Enterobacteriaceae, staphylococci) and is statically different $(\mathrm{p}<0.05)$ from H11- $a$ and H11- $b$ productions. On the other hand, the lowest values of histamine $(27.16 \mathrm{mg} / \mathrm{kg}$ and $33.61 \mathrm{mg} / \mathrm{kg}$ in H11- $a$ and $b$, respectively) were obtained for salted anchovies inoculated with the strain H11, even though only the H11-b thesis showed statistically significant differences $(p<0.05)$ with Control 1- $b$, H2- $a$, H4- $a$, H4- $b$, H6- $a$, H8- $a$, H9- $a$, H9- $b$ and H10- $a$. The differences in terms of histamine contents might be related to EHA strains used as inoculum and the amount of salt used. EHA strains determined the inhibition of the microbial groups involved in histamine generation. Trial H11-b had very low counts in BP medium compared to the other trials, and Staphylococcus spp. has been identified as a histamine forming bacteria (Hernendez-Herrero et al., 1999). However, all samples showed histamine contents lower than that $(400 \mathrm{mg} / \mathrm{kg})$ indicated by Official Regulation (EC No. 1019/2013).

\section{VOCs in salted anchovies}

The results of VOCs emitted by salted anchovies sampled at day 150 are reported in Table 2. A total of 25 different compounds, including mainly hydrocarbons, alcohols, aldehydes and ketones were identified. About $90 \%$ of VOCs were represented by hydrocarbons, followed by alcohols (5\%), and aldehydes (1\%).

Among hydrocarbons, pentadecane and hexadecane were the most represented compounds. Pentadecane is one of the indicators of fish quality (Edirisinghe et al., 2007). This compound was found at high concentration for all productions $b$ inoculated with halophilic strains and mainly for the trials inoculated with the strain H11. 


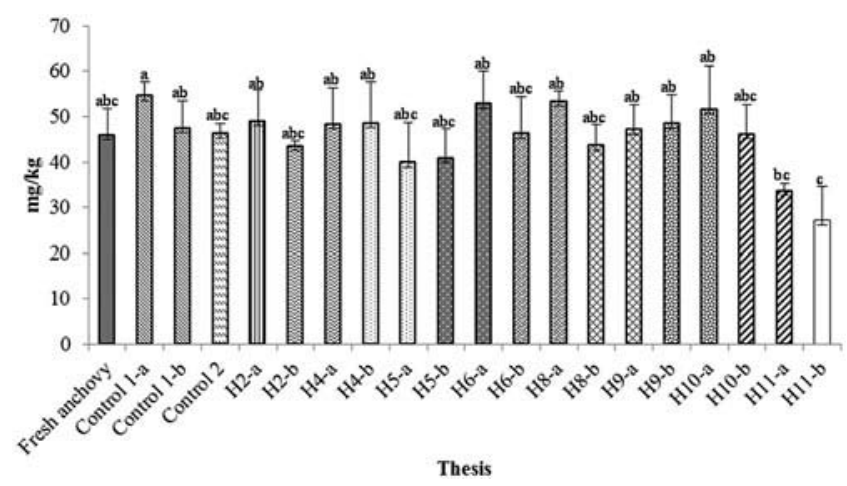

Figure 3. Values of histamine ( $\mathrm{mg} / \mathrm{kg}$ ) determined in the experimental salted anchovies at the end of the ripening period ( $150 \mathrm{days}) . \mathrm{H} 2$, $\mathrm{H} 4, \mathrm{H} 5, \mathrm{H} 6, \mathrm{H} 8, \mathrm{H} 9, \mathrm{H} 10, \mathrm{H} 11$ refer to codes of Halobacterium salinarum strains used as inoculum. The italic letters $a$ and $b$, associated to codes of samples refer to the amounts of salt, 125 and $175 \mathrm{~g} / \mathrm{kg}$ respectively, used to produce salted anchovies; Control 2, experimental production obtained by $500 \mathrm{~g}$ salt per $1 \mathrm{~kg}$ anchovies. Different letters superscript on quantities of histamine indicate significant differences according to Tukey's test between experimental productions for $p \leq 0.05$.

Within the class of alcohols, 2-propyl-1-pentanol reached the highest concentration. This compound is generally associated with green banana flavor (Baranska et al., 2013). The 1-octen3-ol, a compound associated with mushroom-like flavor (Triqui et al., 1995a), was mainly detected in controls 1- $a$ and 1- $b$. Aldehydes were mainly represented by benzaldehyde, which is recognized as a final product of the amino acid catabolism (Sinz et al., 2012), as well as by (E)-2-heptenal, (E,E)-2,4-heptadienal, and (E,E)-3,5-octadien-2, reported to derive from the oxidation of linoleic (Grosch, 1987), a-linolenic, and eicosapentaenoic acids (Frankel, 1983; Kawai et al., 1996), respectively. In addition, the (E,E)-2,4-heptadienal was found responsible for fatty and rancid flavors (Triqui, 1995a). The concentrations of these compounds were significantly higher in the control productions.

Among ketones, 2,3-octanedione and 2-nonanone have been found to be associated with oxidation (Young et al., 1997) and autoxidation (Dehaut et al., 2014) of fatty compounds, respectively. The 2-nonanone and (E,E)-3,5-octadien-2-one were associated with the green and marine algae-like sensory descriptors in salted anchovies (Triqui et al., 1995a). Thus, many VOCs from oxidation and/or autoxidation of fatty compounds might be responsible for the characteristic flavor of salted anchovies (Czerner et al., 2011; Triqui et al., 1995a,b, 1999).

The effect of the salt amount on flavor of salted anchovies has been shown by Triqui et al. (1995b), who found a correlation between fatty oxidations, VOCs composition, and the amount of salt used to produce salted anchovies.

\section{Sensory analysis}

The sensory evaluation of the salted anchovies is shown in Table 3. The anchovies inoculated with EHA were similar to that of control production in terms of color uniformity, color intensity, compactness, gumminess, and ham flavor. The main differences were estimated in terms of juiciness. Overall, the inoculated anchovies were the most appreciated by the tasters, and the productions $\mathrm{H} 2$ and $\mathrm{H} 11$ with salt amount $b$ showed the highest scores of overall enjoyment. In detail, the inoculated trials were characterized by higher scores of juicy descriptor, while the values of rancid and putrid were variable. The values of rancid and putrid scores might be due to proteolytic and lipolytic activities of different EHA strains used as starter. Both the hydrolytic activity on lipids and proteins, as well as the ability to decarboxylate amino acids is highly variable and depends on species, strains, and environmental conditions (Bardocz et al., 1999; De Lourdes 


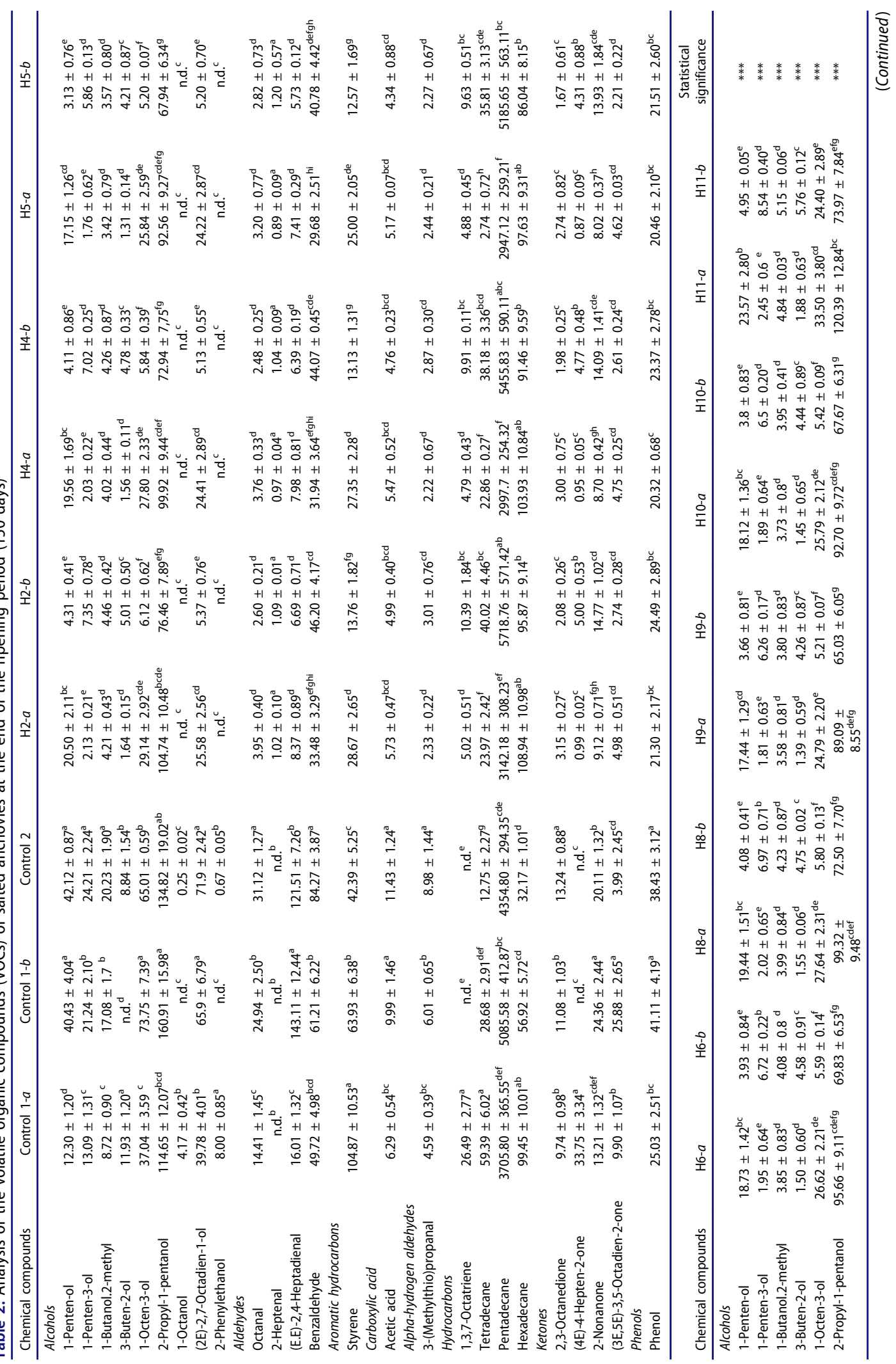




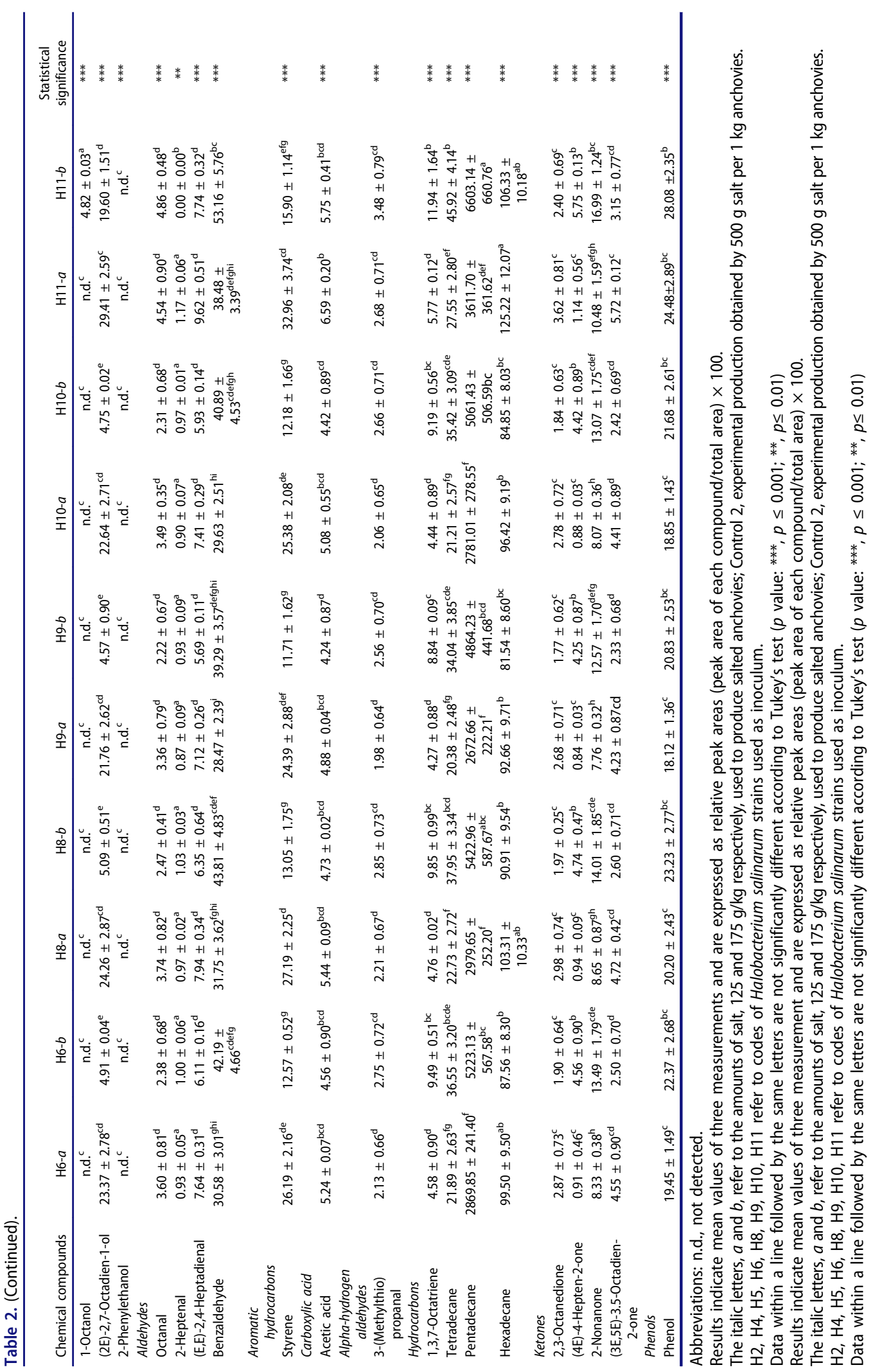




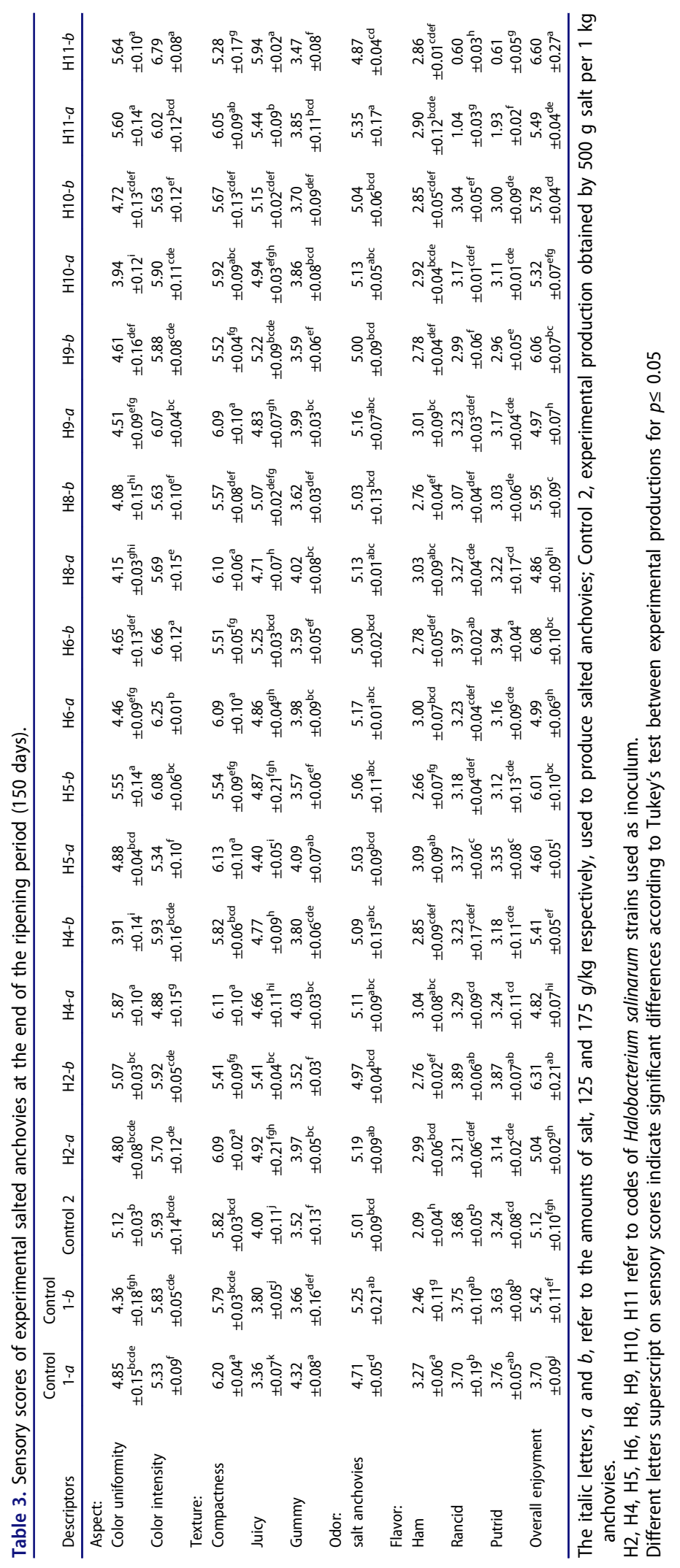


Moreno et al., 2009; Kameura et al., 1986). However, both productions carried out with the H11 strain showed the lowest scores of rancid and putrid and were significantly lower than the score associated with the ham descriptor.

\section{Multivariate statistical analyses}

HCA classified the productions in accordance to their mutual dissimilarity and relationship. This analysis classified trials using 19 variables selected on the basis of results from microbial monitoring, histamine, VOCs profiles, and sensorial analyses (Figure 4). Except for controls, all experimental productions were clearly separated into two mega-clusters. Furthermore, within each mega-cluster, two groups at low level of dissimilarity (dissimilarity by Euclidean distance $<20 \%$ ) were found on the basis of the amount of salt used. Among trials, the production carried out with strain H11 and with a lower salt amount (a) was separated from all other experimental productions.

The results from microbial counts and histamine and VOC concentrations, as well as from sensory analysis were also subjected to PCAn (Figure 5), which mainly confirmed the distribution of trials obtained by HCA. In detail, a total of three factors (accounting for 51.57, 20.13, and $10.71 \%$ of the total variability) showing an eigen-value higher than 1 were found. These results indicated that the initial 19 variables (used as data matrix for PCAn) might be expressed as linear combination of three factors explaining up to $82.41 \%$ of the total variability.

The components of the PCAn were correlated to variables as represented by a bi-plot graph that explained $71.70 \%$ of the total variability as function of factors 1 and 2 . In detail, Figure 5 mainly highlights the discrimination of experimental productions along Factor 1 on the basis of microbial counts and VOCs profiles. In addition, a visible separation resulted between inoculated productions and controls. With regard to factor 2, overall enjoyment, histamine, and hydrocarbons mainly affected the distribution of samples, grouping them according to the amounts of salt used. The production obtained with strain H11- $b$ were slightly separated from all others trials.

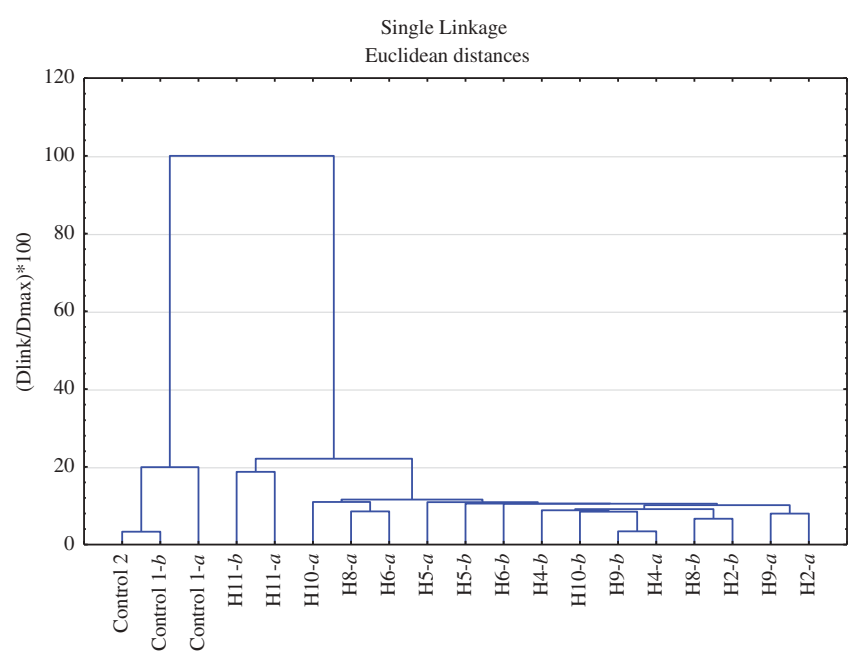

Figure 4. Dendrogram of salted anchovy samples resulting from HCA analysis based on values of microbiological loads, histamine and VOC concentrations, as well as sensory scores. $\mathrm{H} 2, \mathrm{H} 4, \mathrm{H} 5, \mathrm{H} 6, \mathrm{H} 8, \mathrm{H} 9, \mathrm{H} 10, \mathrm{H} 11$ refer to codes of Halobacterium salinarum strains used as inoculum. The italic letters $a$ and $b$, associated to codes of samples refer to the amounts of salt, $125 \mathrm{and} 175 \mathrm{~g} / \mathrm{kg}$ respectively, used to produce salted anchovies; Control 2, experimental production obtained by $500 \mathrm{~g}$ salt per $1 \mathrm{~kg}$ anchovies. 


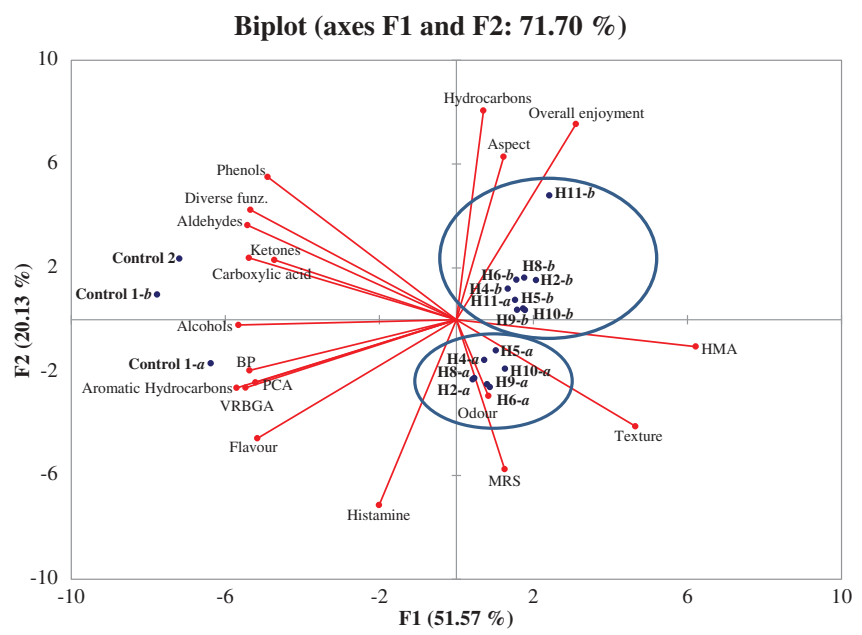

Figure 5. PCAn analysis based on microbiological loads, histamine and VOCs concentrations, as well as sensory scores of the experimental salted anchovies. Bi-plot graphs show relationships among factors, variables, and samples. H2, H4, H5, H6, H8, H9, $\mathrm{H} 10, \mathrm{H} 11$ refer to codes of Halobacterium salinarum strains used as inoculum. The italic letters $a$ and $b$, associated to codes of samples refer to the amounts of salt, 125 and $175 \mathrm{~g} / \mathrm{kg}$, respectively, used to produce salted anchovies; Control 2, experimental production obtained by $500 \mathrm{~g}$ salt per $1 \mathrm{~kg}$ anchovies.

\section{Conclusion}

The inoculum of strain Hbt. salinarum H11 in concomitance with a low amount of salt inhibited the growth of undesired microbial populations. In particular, salted anchovies produced with strain H11 showed the lowest histamine content in respect to the other experimental productions and also gained the best sensory evaluation. Furthermore, results obtained by using $175 \mathrm{~g}$ of salt per $\mathrm{kg}$ of anchovies compared to the amount used in traditional protocols $(500 \mathrm{~g} / \mathrm{kg})$ did not alter the quality of the final product. Even though the application of strain Hbt. salinarum $\mathrm{H} 11$ at an industrial level needs to be further investigated, based on these findings, it can be concluded that both inoculum of EHA strains and a salt amount might affect quality of salted anchovies.

\section{Acknowledgments}

The authors wish to thank the enterprise Saline Infersa and Dr. Franco Rallo for their significant support with the sampling of salt samples.

\section{Funding}

This work was financially supported by the project PON02_00451_3362121 PESCATEC "Development of a sustainable and competitive Sicilian fishery through technological innovation" of the Italian Ministry of Education, University and Research.

\section{References}

Akolkar, A. V., Durai, D., and Desai, A. J. 2010. Halobacterium sp. SP1 (1) as a starter culture for accelerating fish sauce fermentation. J. Appl. Microbiol. 109: 44-53.

Altschul, S. F., Madden, T. L., Schäffer, A. A., Zhang, J., Zhang, Z., and Miller, W. 1997. Grapped BLAST and PSIBLAST: A new generation of protein database search programs. Nucleic Acids Res. 25: 3389-3402.

APHA. 2015. Compendium of Methods for the Microbiological Examination of Foods, 5th Edition. New York: APHA Press.

Aponte, M., Blaiotta, G., Francesca, N., and Moschetti, G. 2010. Could halophilic archaea improve the traditional salted anchovies (Engraulis encrasicholus L.) safety and quality? Lett. Appl. Microbiol. 51(6): 697-703. 
Bakke, M., Sato, T., Ichikawa, K., and Nishimura, I. 2005. Histamine dehydrogenase from Rhizobium sp.: Gene cloning, expression in Escherichia coli, characterization and application to histamine determination. J. Biotechnol. 119: 260-271.

Baranska, A., Tigchelaar, E., Smolinska, A., Dallinga, J. W., Moonen, E. J., Dekens, J. A., Wijmenga, C., Zhernakova, A., and van Schooten, F. J. 2013. Profile of volatile organic compounds in exhaled breath changes as a result of gluten-free diet. J. Breath. Res. 7(3): 1-10.

Bardocz, S. 1995. Polyamines in food and their consequences for food quality and human health. Trends Food Sci. Technol. 6: 341-346.

Baross, J. A., and Lenovich, L. M. 1992. Halophilic and osmophilic microorganisms. In: Compendium of Methods for the Microbiological Examination of Food. Vanderzant, C., and Splittstoesser, D. F. (Ed.). Washington: American Public Health Association, Pp. 199-223.

Bautista-Gallego, J., Arroyo López, F. N., Romero, G. V., Rodríguez Gómez, F., García-García, P., and Garrido Fernández, A. 2011. Chloride salt mixtures affect Gordal cv. green Spanish-style table olive fermentation. Food. Microbiol. 28: 1316-1325.

Birbir, M., Calli, B., Mertoglu, B., Bardavid, R. E., Oren, H., Oren, A., Ogmen, M. N., and Ogan, A. 2007. Extremely halophilic Archaea from Tuz Lake, Turkey, and the adjacent Kaldirim and Kayacik salterns. World J. Microbiol. Biotechnol. 23: 309-316.

Blana, V. A., Grounta, A., Tassou, C. C., Nychas, G. J. E., and Panagou, E. Z. 2014. Inoculated fermentation of green olives with potential probiotic Lactobacillus pentosus and Lactobacillus plantarum starter cultures isolated from industrially fermented olives. Food. Microbiol. 38: 208-218.

Brown, M. 2008. Chilled Foods: A Comprehensive Guide (Woodhead Publishing Series in Food Science, Technology and Nutrition) 3rd ed. Boca Raton, FL: CRC Press.

Campello, F. 1985. Approche microbiologique de l'anchoitage. ISTPM/R 47(3-4): 217-226.

Caseario, G., and Caramaschi, N. 1993. La microbiologia delle semiconserve ittiche: acciughe sott'olio. (Microbiology of semi preserved fish: Anchovies in oil). Industria Conserve 68: 142-147.

Chun, J., Lee, J. H., Jung, Y., Kim, M., Kim, S., Kim, B. K., and Lim, Y. W. 2007. EzTaxon: A web-based tool for the identification of prokaryotes based on 16S ribosomal RNA gene sequences. Int. J. Syst. Evol. Microbiol. 57: $2259-2261$.

Clucas, I. J. 1982. Salting of fish methods. In: Preservation and Processing: Part 2. Clucas, I. J. (Ed.). London: Fish Handling Report of the Tropical Products Institute. Pp. 4-8.

Commission Regulation (EC) No. 1441/2007 of 5 December 2007 amending Regulation EC) No. 2073/2005 on microbiological criteria for foodstuffs. Off J Eur Union 322:1-18.

Commission Regulation (EC) No. 1019/2013 of 23 October 2013 amending Annex I to Regulation (EC) No. 2073/2005 as regards histamine in fishery products. Off. J. Eur. Union 282: 46-47.

Czerner, M., Tomás, M. C., and Yeannes, M. 2011. Ripening of salted anchovy (E. anchoita): Development of lipid oxidation, color and other sensorial characteristics. J. Sci. Food. Agric. 91(4): 609-615.

Dehaut, A., Himber, C., Mulak, V., Grard, T., Krzewinski, F., Le Fur, B., and Duflos, G. 2014. Evolution of volatile compounds and biogenic amines throughout the shelf life of marinated and salted anchovies (Engraulis encrasicolus). J. Agric. Food. Chem. 62(32): 8014-8022.

De Lourdes Moreno, M., García, M. T., Ventosa, A., and Mellado, E. 2009. Characterization of Salicola sp. IC10, a lipase-and protease-producing extreme halophile. FEMS Microbiol. Ecol. 68(1): 59-71.

Dillon, W. R., and Goldstein, M. 1984. Multivariate Analysis. Methods and Applications. New York: John Wiley and Sons.

Eddy, B. P. 1958. The Microbiology of Fish and Meat Curing Brines. London: H. M. Stationery Off.

Edirisinghe, R. K., Graffham, A. J., and Taylor, S. J. 2007. Characterisation of the volatiles of yellowfin tuna (Thunnus albacares) during storage by solid phase microextraction and GC-MS and their relationship to fish quality parameters. Int. J. Food. Sci. Tech. 42(10): 1139-1147.

Eerola, S., Hinkkanen, R., Lindfors, E., and Hirvi, T. 1992. Liquid chromatographic determination of biogenic amines in gradry sausages. J. Aoac. Int. 76(3): 575-577.

EFSA Panel on Biological Hazards (BIOHAZ). 2011. Scientific Opinion on risk based control of biogenic amine formation in fermented foods. EFSA J. 9(10): 1-93.

FAO. 2014. Yearbook, Fishery and Aquaculture Statistics. Rome, Italy: FAO.

Filsinger, B. E. 1987. Effect of pressure of salting and ripening process of anchovies Engraulis anchoita. J. Food. Sci. 52: 919-922.

Frankel, E. N. 1983. Volatile lipid oxidation products. Prog. Lipid. Res. 22: 1-33.

Giménez, M. I., Studdert, C. A., Sánchez, J. J., and De Castro, R. E. 2000. Extracellular protease of Natrialba magadii: purification and biochemical characterization. Extremophiles 4(3):181-188.

Grant, W. D., Gemmell, R. T., and McGenity, T. J. 1998. Halophiles. In: Extremophiles: Microbial Life in Extreme Environments. Horikoshi, K., and Grant, W. D. (Ed.). New York: Wylei-Liss. Pp. 93-132.

Grosch, W. 1987. Reactions of hydroperoxides - Products of low molecular weight. In: Autoxidation of Unsaturated Lipids. Chan, H. W. (Ed.). London: Academic Press, Pp. 95-139.

Hall, G.M. 1997. Fish Processing Technology. London: Blackie Academic and Professional. 
Hassanshahian, M., and Mohamadian, J. 2011. Isolation and characterization of Halobacterium salinarum from saline lakes in Iran. Jundishapur. J. Microbiol. 4(S1): 59-65.

Heredia, N. 2009. Microbiologically Safe Foods. Hoboken, NJ: John Wiley \& Sons.

Hernández-Herrero, M. M., Roig-Sagués, A. X., López-Sabater, E. I., Rodríguez-Jerez, J. J., and MoraVentura, M. T. 1999. Protein hydrolysis and proteinase activity during the ripening of salted anchovy (Engraulis e ncrasicholus L.). A Microassay Method for Determining the Protein Hydrolysis. J. Agr. Food. Chem. 47(8): 3319-3324.

Hernández-Herrero, M. M., Roig-sagués, A. X., Rodríguez-Jerez, J. J., and Mora-Ventura, M. T. 1999. Halotolerant and halophilic histamine-forming bacteria isolated during the ripening of salted anchovies (Engraulis encrasicholus). J. Food. Protect. 62(5): 509-514.

Holt, J. G., Krieg, N. R., Sneath, P. H. A., Staley, J. T., and Williams, S. T. 2005. Bergey's Manual of Determinative Bacteriology. Philadelphia: Lippincott Williams \& Wilkins.

Ienistea, C. 1971. Bacterial production and destruction of histamine in foods, and food poisoning caused by histamine. Nahrung 15: 109-113.

ISO 5496:2006. 2006. Sensory analysis - Methodology - Initiation and training of assessors in the detection and recognition of odours. https://www.iso.org/obp/ui/\#iso:std:iso:5496:en.

Izotova, L.S., Strongin, A.Y., Chekulaeva, N.L., Sterkin, V.E., Ostoslavskaya, V.I., Lyublinskaya, L.A., Timokhina, E.A., and Stepanov V.M. 1983. Purification and properties of serine protease from Halobacterium halobium. J. Bacteriol. 155(2): 826-830.

Jolliffe, I. T. 1986. Principal Component Analysis. New York: Springer.

Kamekura, M., Bardocz, S., Anderson, P., Wallace, R., and Kushner, D. J. 1986. Polyamines in moderately and extremely halophilic bacteria. Bba-Gen Subj. 880(2): 204-208.

Kamekura, M., Seno, Y., Holmes, M. L., and Dyall-Smith, M. L. 1992. Molecular cloning and sequencing of the gene for a halophilic alkaline serine protease (halolysin) from an unidentified halophilic archaea strain (172P1) and expression of the gene in Haloferax volcanii. J. Bacteriol. 174(3): 736-742.

Karaçam, H., Kutlu, S., and Köse, S. 2002. Effect of salt concentrations and temperature on the quality and shelf-life of brined anchovies. Int. J. Food. Sci. Tech. 37(1): 19-28.

Kawai, T., and Sakaguchi, M. 1996. Fish flavor. Crit. Rev. Food. Sci. Nutr. 36: 257-298.

Lee, H.-S. 2013. Diversity of halophilic archaea in fermented foods and human intestines and their application. J. Microbiol. Biotechnol. 23(12):1645-1653.

Lee, J.-D., Kang, K.-H., Kwon, S.-J., Yoon, M.-J., Park, S.-Y., Park, J.-H., Kim, J,-G. 2015. Changes of physicochemical properties of salted-fermented anchovy meat Engraulis japonica with different salt content during fermentation at $15^{\circ} \mathrm{C}$. JFSME 27(5): 1457-1469.

Lehane, L., and Olley, J. 2000. Histamine fish poisoning revisited: Review. Int. J Food Microbiol. 58: 1-37.

Lupin, H. M., Boeri, R. L. and Moschiar, S. M. 1981. Water activity and salt content relationship in moist salted fish products. Int. J. Food. Sci. Tech. 16(1): 31-38.

Martorana, A., Alfonzo, A., Settanni, L., Corona, O., La Croce, F., Caruso, T., Moschetti, G., and Francesca, N. 2015. An innovative method to produce green table olives based on "pied de cuve" technology. Food Microbiol. 50: 126140.

Moret, S., and Conte, L. S. 1996. High-performance liquid chromatographic evaluation of biogenic amines in foods an analysis of different methods of sample preparation in relation to food characteristics. J. Chromatogr. A. 729(1): 363-369.

Moschetti, G., Aponte, M., Blaiotta, G., Casaburi, A., Chiurazzi, M., Ventorino, V., and Villani, F. 2006. Characterization of halophilic archaea isolated from different hypersaline ecosystems. Ann. Microbiol. 56(2): 119-127.

Oren, A., and Litchfield, D. C. 1999. A procedure for the enrichment and isolation of Halobacterium. FEMS Microbiol. Lett. 173: 353-358.

Oren, A. 2006. The order halobacteriales. Prokaryotes 3: 113-164.

Perez-Villarreal, B., and, Pozo, R. 1992. Ripening of the salted anchovy (Engraulis encrasicholus): Study of the sensory, biochemical and microbiological aspects. In: Quality Assurance in the Fish Industry. Huss, H. H., Jakobsen, M. and Liston, J. (Eds.) Amsterdam, Netherlands: Elsevier Science Publishers. pp. 157-167.

Petter, H. F. M. 1931. On bacteria of salted fish. Proc. Acad. Sci. 34: 1417-1423.

Presad, M., and Panduranga, Rao, C. C. 1995. Heat treatment for elimination of red-halophiles from contaminated solar salt. Fishery Technol. 32(2): 122-125.

Rodríguez-Gómez, F., López-López, A., Romero-Gil, V., Arroyo-López, F. N., Moreno-Baquero, J. M., GarridoFernández, A., and García-García, P. 2014. Effect of post-fermentation storage on Spanish-style green Manzanilla olives. LWT - Food Sci. Technol. 57: 789-793.

Rodriguez-Valera, F., Juez, G., and Kushner, D. J. 1983. Halobacterium mediterranei sp. nov. a new carbohydrateutilizing extreme halophile. Syst. Appl. Microbiol. 4: 369-381.

Ryu, K., Kim, J., and Dordick, J. S. 1994. Catalytic properties and potential of an extracellular protease from an extreme halophile. Enzyme Microb. Tech. 16(4): 266-275. 
Schmitt, W., Rdest, U., and Goebel, W., 1990. Efficient High-performance liquid chromatographic system for the purification of halobacterial serine protease. J. Chromatogr. 521: 211-220.

Shi, W., Tang, X.F., Huang, Y., Gan, F., Tang, B., and Shen, P. 2006. An extracellular halophilic protease SptA from a halophilic archaeon Natrinema sp. J7: gene cloning, expression and characterization. Extremophiles 10(6): 599-606.

Sinz, Q., and Schwab, W. 2012. Metabolism of amino acids, dipeptides and tetrapeptides by Lactobacillus sakei. Food Microbiol. 29: 215-223.

Stackebrandt, E., and Ebers, J. M. T. 2006. Taxonomic parameters revisited: Tarnished gold standards. Microbiol. Today 33: 152-155.

Stepanov, V.M., Rudenskaya, G.N., Revina, L.P., Gryaznova, Y.B., Lysogorskaya, E.N., IYu, F., and Ivanova, I.I. 1992. A serine proteinase of an archaebacterium, Halobacterium mediterranei. A homologue of eubacterial subtilisins. Biochem. J. 285(1): 281-286.

Studdert, C.A., Herrera-Seitz, M.K., Plasencia-Gil, M.I., Sanchez J.J., and De Castro R.E. 2001. Purification and biochemical characterization of the haloalkaliphilic archaeon Natronococcus occultus extracellular serine protease. J. Basic. Microbiol. 41: 375-383.

Tapingkae, W., Tanasupawat, S., Parkin, K. L., Benjakul, S., and Visessanguan, W. 2010. Degradation of histamine by extremely halophilic archaea isolated from high salt-fermented fishery products. Enzyme Microb. Tech. 46(2): 92-99.

Todeschini, R. 1998. Introduzione alla Chemiometria. EdiSES s.r.l., Naples.

Triqui, R., and Reineccius, G. A. 1995b. Flavor development in the ripening of anchovy (Engraulis encrasicholus L.). J. Agr. Food. Chem. 43: 453-458.

Triqui, R., and Reineccius, G. A. 1995a. Changes in flavor profiles with ripening of anchovy (Engraulis encrasicholus). J. Agr. Food. Chem. 43(7): 1883-1889.

Triqui, R., and Zouinc, K. 1999. Sensory and instrumental assessments of the ripening process of anchovy (Engraulis encrasicholus). LWT 32(4): 203-207.

Troller, J.A., and Christian, J.H.B. 1978. Water activity and food. New York: Academic Press.

Vidyasagar, M., Prakash, S., Litchfield, C., and Sreeramulu, K. 2006. Purification and characterization of a thermostable, haloalkaliphilic extracellular serine protease from the extreme halophilic archaeon Halogeometricum borinquense strain TSS101. Archaea 2(1): 51-57.

Villar, M., De Ruiz, Holgado, A. P., Sanchez, J. J., Trucco, R. E., and Oliver, G. 1985. Isolation and characterization of Pediococcus halophilus from salted anchovies (Engraulis anchoita). Appl. Environ. Microbiol. 49: 664-666.

Voskresensky, N. A. 1965. Salting of Herring. New York: Academic Press.

Yeannes, M. I., Ameztoy, I. M., Ramirez, E. E., and Felix, M. M. 2011. Culture alternative medium for the growth of extreme halophilic bacteria in fish products. Ciênc. Technol. Aliment. 31(3): 561-566.

Young, O. A., Berdagué, J. L., Viallon, C., Rousset-Akrim, S., and Theriez, M. 1997. Fat-borne volatiles and sheepmeat odour. Meat Sci. 45: 183-207. 